\title{
Driver Ojek Konvensional Versus Driver Ojek Online di Kota Palembang : Studi Komparasi Kepuasan Kerja Perspektif Psikologi Islam
}

\author{
M. Ridwan Hertarto ${ }^{* a}$, Muhammad Mawangir ${ }^{\text {b }}$, Iredho Fani Reza ${ }^{\mathrm{c}}$ \\ ${ }^{a, b, c}$ Universitas Islam Negeri Raden Fatah Palembang \\ *Corresponding author : ridwan890@gmail.com
}

\begin{abstract}
Abstrak
Penelitian ini membahas tentang kepuasan kerja pada driver ojek konvensional dan driver ojek online. Penelitian ini adalah jenis penelitian kuantitatif dengan rancangan penelitian komparatif. Subjek penelitian berjumlah 200 orang yang terdiri dari 100 driver ojek konvensional dan 100 driver ojek online di Palembang. Metode analisis data yang digunakan untuk menguji hipotesis penelitian menggunakan independent sample t-test. Perhitungan analisis data menggunakan bantuan SPSS versi 22 for windows. Hasil dari penelitian ini menunjukkan bahwa ada perbedaan kepuasan kerja pada driver ojek konvensional dan driver ojek online, dengan nilai t-hitung $(6,702)>$ t-tabel $(1,652)$, dengan nilai signifikansi $0,000<$ 0,05 .
\end{abstract}

\section{Kata Kunci}

Kepuasan Kerja; Ojek Online; Ojek Konvensional

\begin{abstract}
The purpose of this study is want to examine the job satisfaction among conventional ojek driver and online ojek driver. This research is a kind of quantitative research with comparative research design. The subjects of this study were 200 people consisting of 100 conventional ojek driver and 100 online ojek driver in Palembang. Then, data analysis method used to test the research hypothesis using independent sample t-test. In addition, the calculation of data analysis using SPSS version 22 for windows. The results of this study found that there were differencing job satisfaction among conventional ojek driver and online ojek driver, by the value of t-arithmetic $(6,702)>t$-table $(1,652)$, with significance value $0,000<0,05$.
\end{abstract}

\section{Keywords}

Job Satisfaction; Conventional, Online; Ojek Driver 


\section{Pendahuluan}

$\mathrm{K}$ ehadiran teknologi informasi dan teknologi komunikasi telah globalisasi, sehingga berdampak pada semua bidang kehidupan manusia. Globalisasi yang disertai derasnya arus informasi dan teknologi ini, telah menciptakan berbagai tantangan, permasalahan dan juga peluang bagi masyarakat untuk mempermudah akses dan aktivitas dalam kehidupannya. Salah satu dampak positif dari derasnya arus informasi dan globalisasi ini adalah dengan bermunculannya aplikasi-aplikasi yang dapat membantu manusia dalam memenuhi kebutuhannya, seperti layanan perbankan online, belanja online, layanan hotel dan tiket pesawat online, dan termasuk juga ojek online. Ojek online merupakan jenis ojek yang memperoleh order dari pelanggan via aplikasi handphone (HP) dengan kalkulasi biaya otomatis tanpa melibatkan tawar menawar. Ojek online adalah ojek yang berbasis aplikasi HP di mana pelanggan memesan ojek lewat sistem aplikasi di HP. Dalam aplikasi sudah dapat diketahui jarak, lama pemesanan, harga, nama orang yang menjemput, serta perusahaan pengelolaannya (Ojek Online, 2017, 7 November).

Awal mula kemunculan ojek online ini, dilatar belakangi oleh kesemerawutan transportasi di Indonesia dan Jakarta pada khususnya. Sehingga pada tahun 2010, Nadiem Makarim, merasa bahwa transportasi publik di Jakarta perlu untuk diperbaiki. Selain karena sistem layanan angkutan umumnya yang tidak baik, ditambah dengan tarif ojek konvensional yang terkadang sangat tidak bersahabat membuat masyarakat berada pada posisi dilema yaitu terpaksa menggunakan layanan mahal dengan sistem yang tidak memiliki standar. Hal ini berlaku untuk layanan ojek maupun taksi yang membuat Nadiem fokus untuk mendirikan GOJEK (Elshinta.com, 2017, 7 November). Antusiasme masyarakat terhadap ojek onlie dalam bentuk aplikasi GOJEK, telah memicu muncul dan berkembangnya ojek online serupa, seperti Grab, Uber, Blu-Jek, dan Ladyjek, yang mengkhususkan bagi segmen penumpang wanita. Sehingga hal ini juga berdampak pada pembukaan lapangan pekerjaan baru, serta sebagai penambah penghasilan bagi masyarakat yang cukup menjanjikan.

Fenomena ojek online ini bukan hanya terjadi di Jabodetabek, melainkan hampir diseluruh kota- kota di Indonesia, seperti Bandung, Surabaya, Bali, Makassar, Medan, Balik Papan, Palembang dan kotakota lainnya di Indonesia. Kemunculan ojek online, tentu saja diikuti oleh jumlah pengendara ojek online yang banyak. Berdasarkan data, sekarang ini ada sekitar 250.000 orang pengemudi GOJEK (Kumparan.com, 2017, 7 November). Tingginya antusiasme masyarakat untuk menjadi driver ojek online ini disebabkan oleh beberapa hal, seperti tingginya jumlah pengangguran, waktu kerja yang bebas dan fleksibel, serta penghasilan yang menjanjikan. Waktu kerja yang diatur sendiri oleh driver, dan penghasilan yang cukup memuaskan telah mendorong masyarakat semakin berminat untuk bergabung sebagai driver ojek online, sehingga berdampak pada kepuasaan kerja para driver ojek online itu sendiri.

Menurut Howel dan Dipyobe, kepuasaan kerja sebagai hasil keseluruhan dari derajat suka atau tidak sukanya tenaga kerja 
terhadap berbagai aspek dari pekerjaannya (Munandar, 2013). Sebagaimana pendapat Munandar yang mengatakan bahwa salah satu faktor yang menentukan kepuasan kerja adalah gaji pengahsilan. Munandar juga menyatakan bahwa uang mempunyai arti yang berbeda-beda bagi orang yang berbeda-beda (Munandar, 2014: 360). Selain itu, Menurut Smith, Kendall dan Hulin ada lima karakteristik penting yang mempengaruhi kepuasan kerja, yaitu pekerjaan itu sendiri, upah atau gaji, penyelia atau pengawasan kerja, kesempatan promosi, dan rekan kerja (Almigo: 2004). Dampak kepuasan kerja dan ketidak puasan kerja ini akan berakibat terhadap produktivitas, kemangkiran, bahkan keluarnya tenaga kerja, serta kesehatan (Munandar, 2014).

Dari hasil studi pendahuluan yang peneliti lakukan, bahwa terdapat fenomena kesenjangan antara pendapatan driver ojek online dengan driver ojek konvensional. Hal ini senada dengan hasil wawancara yang penulis lakukan dengan JM yang merupakan salah seorang driver (pengemudi) ojek online yang sering berada disekitaran UIN Raden Fatah Palembang. Menurut JM, penghasilannya sebagai pengemudi ojek online bisa mencapai 300 ribu bersih perharinya. Jadi kalau menarik ojek terus selama sebulan bisa mendapatkan sekiatar 9 jutaan (Wawancara JM, 2017, 17 November).

"Berapo yo....hmmm....sekitar 300 ribu bersih sehari. Jadi kalu narik terus sebulan besak jugo...kalike be 300 kali 30 ari...berapo. , sekitar 9 juta. Tapi kalu narik terus. ngojeknyo tiap ari”.

Pernyataan JM tersebut merupakan gambaran penghasilan yang didapatkan oleh para pengemudi ojek online.
Walaupun hal tersebut dinyatakan berbeda oleh BB yang menyatakan bahwa (Wawancara BB, 2017, 17 November).

"Aikalu aku dak sampe mak itu..... iyo...kadang sampai 300 ribu sehari....kadang lebih...kadang kurang jugo.... Kalu sebulan......tekumpul sekitar 5 sampai 7 juta kalu aku...dak tahu kalu yang lain...tapi Alhamdulillah.... cukup besak....pacaklah ngenjuk anak bini makan dan nabung dikit”.

Kedua wawancara yang peneliti lakukan dengan kedua pengendara ojek online tersebut merupakan gambaran penghasilan yang didapatkan oleh para pengemudi ojek online. Artinya, secara penghasilan, para pengendara ojek online ini mempunyai penghasilan yang cukup layak sebagai sebuah pekerjaan dibandingkan dengan pekerjaan lain, seperti karyawan kantoran atau buruh pabrik yang hanya berstandarkan UMR. Oleh karena itulah, ketika penulis menanyakan tentang kepuasan kerja pada kedua pengemudi ojek online tersebut, mereka menyatakan puas dengan pekerjaan mereka, terutama dari segi penghasilan yang mereka dapatkan (Wawancara JM \& BB, 2017, 17 November).

“Alhamdulilllah....besyukur...puaslah...si apo nak ngenjuk duit ngen kito ni dulu aku begawe ngenkoko di Sayangan... woiii saro. Gawenyo saro....keno marah terus.nak bawak duit serratus ribu be sari kerumah saro. apolagi nak bejuta-juta mak ini sebulannyo.... pokoknyo besyukurlah ado yang mak ini....dak boleh dihapus" (Wawancara subjek JM).

"Gawe macam kito ni dengan pendidikan yang tebatas tapi penghasilan lumayan 
besak Alhamdulillah besyukur puaslah aku dulu ngojek jugo tapi belum pakai hp android mak ini yo dapat jugo sampai 200 sehari tapi begebuk nian....kadang ribut jugo ngen kawan...ngen penumpang jugo kadang agang-agangan. Sekarang Alhamdulillah... tinggal jingok hp. cocok kito ambe... Alhamdulillah penghasilan kadang lebih...tapi lemaknyo dak beagangan lagi ngen kawan, dan masalah bayaran jugo, karna sudah ado disano berapo ongkos bayarnyo" (Wawancara subjek BB).

Wawancara dengan pengedara ojek online tersebut menunjukkan adanya kepuasan kerja pada pengemudi ojek online berdasarkan penghasilan yang mereka dapatkan. Akan tetapi, penulis juga menemukan fakta di lapangan bahwa masih banyak juga pengemudi ojek yang tidak berpindah ke ojek online. Setelah peneliti dalami, berbagai alasan juga mereka nyatakan mengapa mereka tetap bertahan menjadi pengemudi ojek pangkalan atau ojek konvensional.

Salah satu alasan dari subjek pengemudi ojek konvensional menyebutkan bahwa ketidak mengertian dirinya tentang teknologi ponsel membuatnya bertahan sebagai pengemudi ojek konvensional. Sementara alasan yang lainnya adalah dari segi penghasilan tidak terlalu jauh berbeda, serta tidak perlu pakai hp yang bagus dan punya banyak pulsa. Berikut petikan wawancara yang penulis lakukan dengan dua orang pengemudi ojek konvensional tersebut (Wawancara KM \& MD, 2017, 18 November).

"Kalu aku ni dak ngerti pakai hp yang apo katonyo...canggih...android...apo si tuo itu namonyo...jadi yo sudah...pening kepalo nak melok-melok wong... inilah yang kupcak...dan memaang gawe aku dari lamo... mangkal be disini... Alhamdulillah masih ado penumpang... masih banyak langgananan aku.....penghasilan jugo Alhamdulillah dapatlah setengah ari kadang 100an" (Wawancara subjek KM).

"Ai dek....neman igo nyari ke wong duit be....nak pakai hp bagus...nak beli pulsa. Nak nelpon penumpang jugo... nak nyetor pulo... sudahlah dibuyanke wong kalu. Kalu aku lemaklah mak ini be...penghasilan aku ngojek disini jugo lumayan. kalu lagi sehat badan biso dapat jugo 100 sampai 200 lebih sari... dak nak nyetor-nyetor. nak beli pulsa idak... ngantuk tiduk... lapar balek kerumah. dekat sinilah" (Wawancara subjek MD).

Membandingkan kedua hasil wawancara tersebut, terlihat bahwa masing-masing pengemudi ojek online dan ojek konvensional sama-sama terlihat menunjukkan kepuasan terhadap pekerjaan mereka dari sisi penghasilan yang mereka dapatkan. Hal ini sesuai dengan pendapat Lawler, yang menyatakan bahwa salah satu penyebab individu akan merasa puas terhadap pekerjaannya adalah upah atau penghasilan (Wijono, 2014:126). Akan tetapi, selain dari upah atau penghasilan tersebut, Munandar juga menyatakan ada beberapa faktor lain yang mempengaruhi kepuasan kerja, yaitu pekerjaan itu sendiri, penyeliaan atau pengawasan, rekan kerja dan kondisi kerja (Munandar, 2014:357363).

Kepuasan kerja adalah suasana psikologis tentang perasaan menyenangkan atau tidak menyenangkan terhadap pekerjaan seseorang. Sementara itu Porter dan Lawler dalam Bavendam, J. menjelaskan bahwa 
kepuasan kerja merupakan bangunan unidimensional, dimana seseorang memiliki kepuasan umum atau ketidakpuasan dengan pekerjaannya (Ruvendi, 2005).Adanya perbedaan tingkat kepuasan kerja ini, menurut Locke seseorang individu akan merasa puas atau tidak puas merupakan sesuatu yang pribadi, tergantung bagaimana ia memersepsikan adanya kesesuaian atau pertentangan antara keinginankeinginannya. Dan hasil keluarnya. Tambahan waktu libur akan menunjang kepuasan tenaga kerja yang menikmati waktu luang setelah bekerja tetapi tidak akan menunjang kepuasan kerja seseorang tenaga kerja lain yang merasawaktu luangnya tidak akan dinikmati (Munandar, 2014). Adanya tingkat kepuasan kerja yang berbeda ini juga sesuai dengan ajaran Islam. Islam, melalui Al qur'an surat AnNisa ayat 32 , menyatakan bahwa :

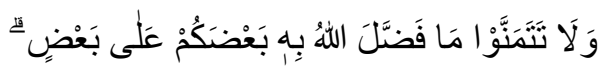

Artinya: Dan janganlah kamu iri hati terhadap karunia yang telah dilebihkan Allah kepada sebagian kamu atas sebagian yang lain (QS. An-Nisa, 32)

Menurut Tafsir Al Muyassar, ayat tersebut menjelaskan bahwa orang yang beriman tidak boleh merasa iri hati terhadap orang lain yang memperoleh karunia lebih banyak dari Allah. Allah SWT sesungguhnya telah menentukan dan mengatur alam ini sedemikian rupa, sehingga ada manusia yang dilebihkan dan diberi keistimewaan oleh Allah. Artinya, melalui ayat tersebut, Allah SWT ingin menjelaskan kepada manusia, bahwasanya penghasilan yang banyak ataupun sedikit yang didapatkan oleh seseorang merupakan ketentuan Allah, sehingga perbedaan dalam penghasilan tersebut hendaklah tidak menjadikan manusia merasa iri dengan yang lainnya (Aidh alQarni, 2007).

Berdasarkan fenomena di lapangan dan pendapat ahli tersebut, maka peneliti tertarik untuk melakukan penelitian tentang perbedaan kepuasan kerja pada driver ojek online dan ojek konvensional di Palembang. Oleh karena itu peneliti mengangkat suatu penelitian yang bertujuan untuk mengetahui perbedaan kepuasan kerja pada driver ojek online dan ojek konvensional di Palembang.

\section{Metode}

Jenis penelitian dalam penelitian ini adalah penelitian dengan metode kuantitatif. Menurut Sugiono Penelitian kuantitatif adalah suatu proses menemukan pengetahuan yang menggunakan data berupa angka sebagai alat menemukan keterangan mengenai apa yang ingin kita ketahui (Sugiono, 2008: 8). Dalam penelitan ini menggunakan satu variabel yaitu Kepuasan kerja dengan membandingkan dua kelompok, yaitu driver ojek online dan driver ojek konvensional. Sebagaimana menurut Charles Ragin, penelitian komparasi adalah penelitian yang cenderung mencari perbedaan antara kasus yang diteliti. Penelitian komparatif meneliti pola persamaan dan perbedaan pada suatu kasus dan mencoba untuk menyimpulkan perbedaan yang ada (Reza, 2017). Populasi adalah keseluruhan subjek penelitian, Azwar mendefinisikan populasi sebagai kelompok subjek yang hendak dikenai generalisasi hasil penelitian. Sebagai suatu populasi, kelompok subjek ini harus memiliki ciri-ciri atau karakteristik 
bersama yang membedakannya dari kelompok subjek lain (Azwar, 2010). Sedangkan menurut Purwanto populasi adalah sekelompok besar individu yang memiliki karakteristik yang sama (Purwanto, 2010).

Adapun populasi dalam penelitian ini adalah driver ojek online dan driver ojek konvensional, dengan karakeristik seperti berikut :

1. Driver ojek online yang berdomisili di kota Palembang.

2. Driver ojek konvensional yang berdomisili di kota Palembang.

3. Telah menjadi driver ojek online ataupun konvensional minimal 1 tahun.

4. Berusia antara 20-40 tahun.

5. Bersedia menjadi responden penelitian.

Untuk menentukan subjek penelitian dilakukan dengan menggunakan teknik sampling kuota. Sampling kuota adalah teknik untuk menentukan sampel dari populasi yang mempunyai ciri-ciri tertentu sampai jumlah yang diinginkan (Sugiyono, 2015).

Menurut Arikunto tekhik sampling ini juga dilakukan tidak mendasarkan diri pada jumlah yang sudah ditentukan. Dalam mengumpulkan data, peneliti menghubungi subjek yang memenuhi persyaratan cirri-ciri populasi tanpa darimana asal subjek tersebut. (asal masih dalam pupulasi yang mudah ditemui sehinggah pengumpulan datanya mudah. Yang penting diperhatikan di sini adalah terpenuhnya jumlah yang telah ditetapkan. (Arikunto, 2013). Sesuai dengan tujuan penelitian ini maka subjek penelitian ini di khususkan pada driver ojek online dan driver ojek konvensional dengan kuota sebanyak 200 orang yang terdiri dari 100 driver ojek onine dan 100 driver ojek konvensional.

Menurut Azwar, metode pengumpulan data dalam penelitian mempunyai tujuan mengungkap fakta mengenai variabel yang diteliti (Azwar, 2011). Adapun cara pengumpulan data dalam penelitian ini adalah dengan menggunakan angket. Angket merupakan teknik pengumpulan data yang dilakukan dengan cara memberi seperangkat pertanyaan atau pernyataan tertulis kepada responden untuk dijawabnya. Angket merupakan teknik pengumpulan data yang efisien bila peneliti tahu dengan pasti variabel yang akan diukur dan tahu apa yang bisa diharapkan dari responden. Menurut Sugiyono tipe pertanyaan dalam angket yang digunakan merupakan pertanyaan tertutup, dan bentuknya menggunakan kalimat positif atau negatif (Sugiyono, 2014). Dalam penelitian ini peneliti menggunakan angket kepuasan kerja yang penulis susun sendiri berdasarkan faktorfaktor kepuasan kerja dari Munandar (2014), yaitu :
a. Pekerjaan
b. Gaji penghasilan
c. Penyelia
d. Rekan kerja
e. Kondisi kerja 


\section{Hasil}

Tabel 1.

Kategorisasi Variable Penelitian

\begin{tabular}{lllcl}
\hline Skor & $\begin{array}{l}\text { Kategor } \\
\text { isasi }\end{array}$ & $\begin{array}{l}\text { Ojek } \\
\text { Online }\end{array}$ & $\begin{array}{l}\text { Ojek } \\
\text { Konve } \\
\text { sional }\end{array}$ & \% \\
\hline $\begin{array}{l}\mathrm{X} \leq \\
88,287\end{array}$ & Rendah & 33 & 1 & $17 \%$ \\
\hline $\begin{array}{l}76,793< \\
X\end{array}$ & Sedang & 62 & 85 & $73,5 \%$ \\
$\begin{array}{l}\text { S8,287 } \\
76,793<\end{array}$ & Tinggi & 5 & 14 & $9,5 \%$ \\
$X$ & & & & \\
\hline \multicolumn{1}{c}{ Total } & & 100 & 100 & $100 \%$ \\
\hline
\end{tabular}

Berdasarkan perhitungan kategorisasi skor variabel kepuasan kerja dapat disimpulkan bahwa nilai tertinggi untuk driver ojek konvensional yaitu 1 orang (1\%), nilai sedang 85 orang ( $85 \%$ ) dan nilai terendah 14 orang $(14, \%)$. Sedangkan untuk driver ojek online nilai tertinggi 33 orang (33\%), nilai sedang 62 orang $(62,90 \%)$, dan nilai terendah 5 orang $(5 \%)$. Jadi dari penjelasan di atas kepuasan kerja pada driver ojek online lebih tinggi (33\%) dari kepuasan kerja pada driver ojek konvensional yang hanya $(1 \%)$.

\section{Uji Normalitas}

\section{Tabel 2.}

Deskripsi Hasil Uji Normalitas

\begin{tabular}{llll}
\hline Variabel & $\begin{array}{l}\text { Kolmogoro } \\
\text { v-Smirnov } \\
\mathbf{Z}\end{array}$ & $\begin{array}{l}\text { Sig } \\
(\mathbf{p})\end{array}$ & $\begin{array}{l}\text { Ket } \\
\cdot\end{array}$ \\
\hline $\begin{array}{l}\text { Driver Ojek } \\
\text { Konvensional }\end{array}$ & 0,177 & 0,200 & $\begin{array}{l}\text { Nor } \\
\text { mal }\end{array}$ \\
\hline $\begin{array}{l}\text { Driver ojek } \\
\text { Online }\end{array}$ & 0,186 & 0,200 & $\begin{array}{l}\text { Nor } \\
\text { mal }\end{array}$ \\
\hline
\end{tabular}

Berdasarkan table deskripsi hasil uji normalitas di atas, maka dapat diterangkan bahwa: Hasil uji normalitas terhadap variabel kepuasan kerja pada driver ojek konvensional memiliki nilai K-SZ sebesar
0,177 dengan signifikan 0,200. Berdasarkan data tersebut, maka dapat dikatakan bahwa nilai signifikan kepuasan kerja pada driver ojek konvensional lebih besar dari 0,05 , sehingga dapat dinyatakan bahwa data variabel kepuasan kerja pada driver ojek konvensional berdistribusi normal. Hasil uji normalitas terhadap variabel kepuasan kerja pada driver ojek online memiliki nilai K-SZ sebesar 0,186 dengan nilai signifikan 0,200. Berdasarkan data tersebut, maka dapat dikatakan bahwa nilai signifikan kepuasan kerja pada driver ojek online lebih besar dari 0,05, sehingga dapat dinyatakan bahwa data variabel kepuasan kerja pada driver ojek online berdistribusi normal.

\section{Uji Homogenitas}

Tabel 3.

Deskripsi Hasil Uji Homogenitas

\begin{tabular}{ccc}
\hline Levene Statistic & Sig (p) & Ket. \\
\hline 2,644 & 0,107 & Homogen \\
\hline
\end{tabular}

Hasil homogenitas menunjukkan bahwa taraf signifikansi data adalah 0,107. Berarti nilai signifikansi lebih besar dari 0,05 $(0,107>0,05)$ maka dapat disimpulkan bahwa kedua kelompok data mempunyai varian yang sama atau homogen.

\section{Uji Hipotesis}

Untuk mengetahui ada tidaknya perbedaan kepuasan kerja pada driver ojek konvensional dan driver ojek online maka dilakukan analisis Indipendent Sampel TTest, dengan aturan jika $\mathrm{t}$ hitung $<\mathrm{t}$ tabel maka Ho diterima, dan Ha ditolak, jika $\mathrm{t}$ hitung > t tabel maka Ho ditolak, dan $\mathrm{Ha}$ diterima. Uji Hipotesis dilakukan dengan bantuan SPSS versi 22,0 for windows. Berikut tabel hasil uji Hipotesis menggunakan uji-t. 


\section{Hasil Uji Hipotesis Independent Sampel T-Test}

Tabel 4.

Deskripsi Hasil Uji Hipotesis

\begin{tabular}{ccccc}
\hline Variabel & $\begin{array}{c}\text { Mean } \\
\text { Difference }\end{array}$ & T & df & $\begin{array}{c}\text { Sig } \\
(\mathbf{p})\end{array}$ \\
\hline $\begin{array}{c}\text { Kepuasa } \\
\text { n Kerja }\end{array}$ & 4,930 & 6,7 & 198 & $\begin{array}{c}0,0 \\
0\end{array}$ \\
\hline
\end{tabular}

Berdasarkan tabel di atas, didapat nilai thitung sebesar 6,702 dan df sebesar 198. Seperti kaidah disebutkan di atas, kaidah yang dipakai dalam penarikan kesimpulan adalah dengan membandingkan nilai $\mathrm{t}$ hitung dan t-tabel. Nilai t-tabel yang didapat dengan df sebesar 198 pada $\mathrm{p}=$ 0,05 adalah 1,652. Perbandingan t-hitung dan $\mathrm{t}$ - tabel pada $\mathrm{p}=0,05$ menunjukkan $\mathrm{t}$ hitung > t-tabel $(6,702>1,652)$. Untuk lebih jelasnya bisa dilihat pada tabel dibawah ini :

\section{Tabel 5.}

Deskripsi Perbandingan T-Hitung dan TTabel

\begin{tabular}{ccccc}
\hline $\begin{array}{c}\text { T- } \\
\text { Hitu } \\
\text { nga }\end{array}$ & $\begin{array}{c}\text { T- } \\
\text { Tabe } \\
\mathbf{l}\end{array}$ & $\begin{array}{c}\text { Permba } \\
\text { ndingan }\end{array}$ & $\begin{array}{c}\text { Sig } \\
(\mathbf{p})\end{array}$ & Ket. \\
\hline 6.702 & 1,65 & $\begin{array}{c}\text { T- } \\
\text { Hitung }>\end{array}$ & 0,0 & Ho \\
& 2 & $\begin{array}{c}\text { Ditolak } \\
\text { T-Tabel }\end{array}$ & &
\end{tabular}

Dari penjelasan diatas, dapat disimpulkan bahwa terdapat perbedaan kepuasan kerja pada driver ojek konvensional dan driver ojek online.

\section{Diskusi}

Penelitian ini menggunakan uji komparatif independent sample t-test yang digunakan untuk melihat perbedaan antara dua kelompok. Dua kelompok yang diuji yaitu driver ojek konvensional dan driver ojek online. Berdasarkan hasil perhitungan statistik yang telah dilakukan oleh peneliti maka didapat nilai t-hitung $(6,702)>$ nilai ttabel (1,652) dengan nilai signifikansi sebesar 0,000. Hal ini menunjukkan bahwa adanya perbedaan kepuasan kerja pada driver ojek konvensional dan driver ojek online. Dimana kepuasan kerja pada driver ojek online lebih tinggi dibandingkan kepuasan kerja pada driver ojek konvensional.

Perbedaaan kepuasan kerja pada driver ojek konvensioal dan driver ojek online tersebut juga terlihat dari hasil penelitian yang menunjukkan bahwa kepuasan kerja pada driver ojek online lebih tinggi dibadingkan dengan driver ojek konvensional yang dapat dilihat dari hasil penilaian berdasarkan kategorisasi dimana nilai tertinggi driver ojek online yaitu sebesar $33 \%$ dari 100 orang, dan nilai tertinggi skor kepuasan kerja driver ojek konvensional hanya sebesar $1 \%$ dari 100 orang yang diambil datanya. Berdasarkan perbandingkan antara mean empirik dan mean hipotetik, dimana mean empirik sebesar 82,54, dan mean hipotetik sebesar 51. Hal ini menunjukkan bahwa mean empirik lebih besar daripada mean hipotetik. Oleh karena itu dapat disimpulkan bahwa pada umumnya ada perbedaan kepuasan kerja pada driver ojek, dimana driver ojek online lebih tinggi kepuasan kerjanya dibandingkan dengan kepuasan kerja driver ojek konvensional. Adanya perbedaan kepuasan kerja pada driver ojek konvensional dan driver ojek online ini menurut Munandar (2014) dibebabkan oleh beberapa faktor, seperti gaji penghasilan, penyelia, rekan sekerja, kondisi kerja dan tentunya juga adalaha pekerjaan itu sendiri.

Pekerjaan sebagai driver ojek, disatu sisi mungkin dianggap sebagian orang sebagai 
pekerjaan yang tidak prestisius (tidak bergengsi), karena tidak memerlukan syarat-syarat yang berat, seperti tingkat pendidikan, spesifikasi keahlian, dan keterampilan khusus yang diperlukan. Seorang driver ojek cukup mempunyai kendaraan bermotor dan teramapil menggunakannya yang dibuktikan dengan kepemilikan Surat Izin Mengemudi (SIM). Walau pun pekerjaan sebagai driver tidak terlalu bergengsi, banyak masyarakat di Indonesia yang menekuni pekerjaan sebagai driver ojek, baik itu sebagai pekerjaan yang full time, atau pun partime (sambilan).

Tingginya antusiasme masyarakat untuk menjadi driver ojek, khususnya ojek online, disebabkan oleh beberapa hal seperti tingginya jumlah pengangguran, waktu kerja yang bebas dan fleksibel, serta penghasilan yang menjanjikan. Waktu kerja yang diatur sendiri oleh driver, dan penghasilan yang cukup memuaskan telah mendorong masyarakat semakin berminat untuk bergabung sebagai driver ojek online, sehingga berdampak pada kepuasaan kerja para driver ojek online itu sendiri. Hal ini sesuai dengan pendapat Munandar (2014: 360) yang mengatakan bahwa salah satu faktor yang menentukan kepuasan kerja adalah gaji penghasilan. Artinya, penghasilan yang didapatkan oleh para driver ojek, secara umum dapat memenuhi kebutuhan hidup para driver ojek, baik itu driver ojek konvensional atau pun driver ojek online. Hal ini sesuai dengan data yang peneliti dapatkan melalui wawancara kepada driver ojek, baik online atau pun yang konvensional. Para driver menyatakan bisa mendapatkan penghasilan antara 100 ribu sampai dengan 300 ribu perhari.
Munandar (2014) selanjutnya juga menyatakan bahwa penghasilan dalam bentuk uang mempunyai arti yang berbedabeda bagi setiap orang. Maksudnya adalah, seberapa besar uang (penghasilan) yang diterima seseorang akan menjadi faktor yang menentukan rasa puas ataupun ketidak puasan seseorang pada pekerjaannya. Inilah salah satu alasan maraknya orang-orang beralih profesi menjadi driver ojek, khususnya driver ojek online, walau pun pekerjaan itu sendiri bukanlah suatu bentuk pekerjaan yang bernilai tinggi (prestisius), tetapi cukup mendatangkan penghasilan yang dapat memenuhi kebutuhan hidup pada driver ojek. Dalam pandangan Islam, rasa puas atau ketidak puasan seseorang terhadap pekerjaan yang dilakukan akan berhubungan dengan keikhlasan, kesabaran dan kemampuan bersyukur seseorang. Ketiga hal tersebut sangat berkaitan dengan permasalahan yang muncul dalam bekerja terutama kepuasan kerja sebagai driver ojek. Kepuasan kerja mengacu pada sikap individu secara umum terhadap pekerjaannya dapat juga dikatakan sebagai persepsi awal terhadap keberhasilan suatu pekerjaan.

Kepuasan kerja dalam Islam dilandasi dengan rasa ihklas (Wordpress.com, 2017, 5 Desember). Ikhlas disini lebih menekankan pada ikhlas dalam menjalani profesi sebagai driver ojek. Dari keikhlasan yang dimiliki ini akan menumbuhkan kesabaran dan mendorong para driver ojek untuk bersyukur pada apa yang didapatkan. Bekerja dengan ikhlas, sabar dan syukur kadang-kadang memang tidak menjamin dapat menaikkan pendapatan, tetapi sebagai proses, bekerja dengan ketiga aspek tersebut dapat memberikan nilai tersendiri. Ikhlas merupakan salah satu dari 
berbagai amal hati, dan bahkan ikhlas berada dibarisan pemula dari amal-amal hati. Menurut Sudirman Tebba, ihklas berati murni atau bersih, maksudnya suatu amal perbuatan dilakukan bersih tanpa pamrih. Amal itu dilaksanakan sematamata karena Allah atau menegakkan kebenaran, keadilan dan kejujuran, bukan karena mencari pujian, popularitas, uang atau kekuasaan (Irham, 2012: 33).

Berikut firman Allah yang terdapat dalam ayat Al-Qur'an yang memerintahkan untuk bersikap ihklas, yaitu terdapat pada Q.S. Lukman 22:

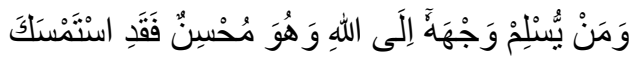

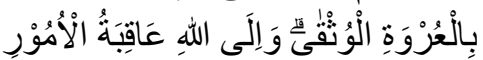

Artinya: dan Barangsiapa yang menyerahkan dirinya kepada Allah, sedang Dia orang yang berbuat kebaikan, Maka Sesungguhnya ia telah berpegang kepada buhul tali yang kokoh. dan hanya kepada Allah-lah kesudahan segala urusan. (Q.S. Lukman: 22)

Tafsir Al Muyassar, ayat tersebut menjelaskan bahwa barang siapa melakukan ketaatan pada Tuhannya dengan ikhlas dan mengesakanNYA, berarti dia telah berkata dan berbuat dengan sebaik-baiknya serta memperbaiki keadan-keadaannya, maka dia telah komit pada amalan utama yang mengundang ridho Allah dan rahmatNYA. Hanya kepada Allah yang Maha Esa semua urusan kembali dan berakhir. Semua orang akan berpulang kepadaNYA dan Allah akan memberi pahala kepada orang yang berbuat baik dan akan menghukum orang yang durhaka (Al- Qarni, 207: 378)

Dalam Q.S. An-Nisa: 125 Allah juga mengatakan bahwa orang-orang yang ikhlaslah yang lebih baik agamanya, yaitu:

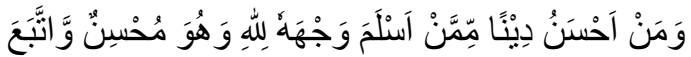

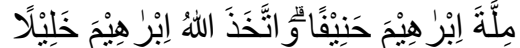

Artinya: dan siapakah yang lebih baik agamanya dari pada orang yang ikhlas menyerahkan dirinya kepada Allah, sedang diapun mengerjakan kebaikan, dan ia mengikuti agama Ibrahim yang lurus?. (An- Nisa;125)

Tafsir al Muyassar menerangkan ayat diatas dengan bahasa tidak ada seorang yang lebih baik agamanya, lebih lurus jalannya, dan lebih jelas manhajnya dari orang yang tunduk pada hukum Rabb-nya, taat kepada Tuhannya, dan menjauhi setiap yang diharamkan oleh Allah Swt, selalu taat kepada Rabbnya dan sunnah nabiNYA, selalu berusaha dalam ketaatan kepada Tuhan dan penciptanya, dan kemudian dia mengikuti agama terbaik, yaitu agama Ibrahim a.s, agama Islam, agama yang toleran dan mudah (Al-Qarni, 2007: 446).

Melalui tafsir Al Muyassar, kedua ayat diatas menjelaskan bahwasanya keikhlasan merupakan kunci dari amal perbuatan yang dilakukan seseorang, termasuk juga keikhlasan dalam bekerja sebagai driver ojek. Driver ojek yang bekerja dengan ikhlas, maka driver ojek tersebut akan bekerja tanpa kenal lelah dan keluh kesah serta konsisten sampai tujuannya tercapai. Sikap ikhlas juga membuat para driver berhati-hati terhadap pekerjaannya berdampak terhadap orang lain (penumpang). Bila pekerjaan itu tidak memenuhi target kualitas, kuantitas dan waktu pengantarannya akan merugikan orang lain (Tebba, 2008: 34). 
Kepuasan kerja pada driver ojek juga berkaitan dengan sikap sabar. Sabar menurut syariat adalah menahan diri dari keluhan dan kemarahan, menahan lidah dari keluh kesah, dan menahan anggota badan dari berbuat kekacauan. Hal ini benar, apabila seseorang dapat menahan dirinya dengan penuh keimanan dan meliputi enam rukun-rukunnya, yaitu iman kepada Allah, malaikat-malaikat-Nya, Kitab-kitab-Nya, rasul-rasul-Nya, hari kiamat, dan qadar, baik dan buruknya (Fadaq, 2002: 49). Driver ojek tidak akan dapat bekerja disiplin, kerja keras kalau tidak memiliki kesabaran. Sebagai driver ojek banyak tantangan seperti sangat lelah, menguras tenaga dan pikiran (stress) akibat macet, ada jam-jam sibuk yang harus dijalani, dan ada target (poin) yang harus di capai. Semua ini tidak dapat dilakukan tanpa kesabaran (Fadaq, 2002: 40). Allah juga memberikan balasan kepada mereka yang bersikap sabar dalam menghadapi setiap kesulitan. Firman Allah SWT tersebut terdapat dalam QS. AlInsan: 12, yaitu:

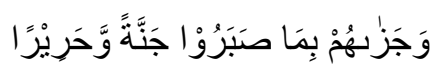

Artinya: dan Dia memberi balasan kepada mereka karena kesabaran mereka (dengan) surga dan (pakaian) sutera. (QS. Al- Insan:12)

Tafsir Khuluqun Azhim menjelaskan ayat tersebut seolah-olah tidak cukup dan belum memadai, kalau hanya terlindung dari kesusahan pada hari itu. Allah memberikan berbagai anugrah kenikmatan lagi kepada orang-orang Abrar, yang telah memilih jalan hidayah tersebut. Allah juga memberi balasan anugrah kepada mereka karena kesabaran mereka dalam keteguhan menjalankan tuntunan dan aturan Allah, yakni anugrah dengan syurga dan pakaian sutra yang indah dan membanggakan (Yunan Yusuf, 2013: 606).

Kesabaran dalam menjalankan perintah Allah dan menjauhi larangannya, dianugrahi Allah masuk kedalam syurga dan memakai pakaian sutra yang indah. Anugrah Allah berupak kenikmatan syurga ini diberikan karena kesabaran atau konsistensi dalam melaksanakan dan menjauhi larangan Allah. Syurga digambarkan sebagai kebun yang indah dengan berbagai buah yang ranum dan lezat cita rasanya (Yunan Yusuf, 2013: 606-607). Dalam konteks bekerja dan mencari nafkah, maka kesabaran itu akan membuahkan hasil berupa rezeki dari Allah untuk memenuhi kebutuhan pangan, sandang dan papan.

Banyak tantangan dalam mencari nafkah sebagai driver ojek, terutama nafkah yang halal, seperti harus bersaing dengan dengan driver ojek lain yang melakukan pekerjaan serupa, pekerjaannya sangat berat, resikonya sangat besar, dan sebagainya. Semua ini tidak bisa dijalani tanpa kesabaran (Fadaq, 2002: 32). Jadi sebagai driver ojek akan merasakan kepuasan dalam bekerja walapun banyak tantangan dijalanan yang dihadapi.

Robbin, menjelaskan bahwa kepuasan kerja adalah sikap umum terhadap pekerjaan seseorang, yang menunjukkan perbedaan antara jumlah penghargaan yang diterima pekerja dan jumlah yang mereka yakini seharusnya mereka terima (Wibowo, 2016: 415). Driver ojek yang memiliki kesabaran tidak akan mengeluh tentang besar kecilnya imbalan dan tantangan dijalanan dan akan tetap bekerja dengan baik. Al-Quran memandang kerja 
sebagai semangat positif yang diberi apresiasi. Salah satu apresiasi Al-Quran adalah apabila salah dalam berbuat tidak dibalas kecuali setimpal dengan perbuatan itu sendiri. Terhadap kegiatan yang positif, Al-Quran menjanjikan kepada pelakunya balasan yang melebihi apa yang dikerjakan (Munir, 2011: 08).

Kepuasan kerja adalah suasana psikologis tentang perasaan menyenangkan atau tidak

menyenangkan terhadap pekerjaan seseorang. Sementara itu Porter dan Lawler dalam Bavendam, J menjelaskan bahwa kepuasan kerja merupakan bangunan unidimensional, dimana seseorang memiliki kepuasan umum atau ketidakpuasan dengan pekerjaannya (Ruvendi, 2005). pendapat ini semakin menegaskan bahwa pada dasarnya setiap individu mempunyai tingkat kepuasan kerja yang berbeda dalam memandang pekerjaannya, begitu juga pada pengendara atau driver ojek konvensional dan driver ojek online.

Locke, menjelaskan bahawa adanya perbedaan kepuasan kerja individu disebabkan karena adanya perbedaan masing-masing individu yang mencakup dua hal, yakni pertentangan tentang apa yang dipersepsikan individu dengan apa yang diterimanya, dan pentingya apa yang diinginkan individu, sehingga setiap individu akan memiliki tingkat kepuasan kerja yang berbeda-beda sesuai dengan sistem nilai yang berlaku pada dirinya (Munandar, 2014: 354-355). Adanya tingkat kepuasan kerja yang berbeda ini juga sesuai dengan ajaran Islam. Islam, melalui Al qur'an surat An- Nisa ayat 32, menyatakan bahwa :

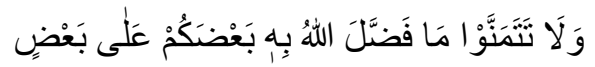

Artinya: "Dan janganlah kamu iri hati terhadap karunia yang telah dilebihkan Allah kepada sebagian kamu atas sebagian yang lain”. (QS. An-Nisa, 32)

Menurut Tafsir Al Muyassar, ayat tersebut menjelaskan bahwa orang yang beriman tidak boleh merasa iri hati terhadap orang lain yang memperoleh karunia lebih banyak dari Allah. Allah swt sesungguhnya telah menentukan dan mengatur alam ini sedemikian rupa, sehingga ada manusia yang dilebihkan dan diberi keistimewaan oleh Allah. Artinya, melalui ayat tersebut, Allah swt ingin menjelaskan kepada manusia, bahwasanya penghasilan yang banyak ataupun sedikit yang didapatkan oleh seseorang merupakan ketentuan Allah, sehingga perbedaan dalam penghasilan tersebut hendaklah tidak menjadikan manusia merasa iri dengan yang lainnya (Aidh al-Qarni: 2007).

\section{Kesimpulan}

Berdasarkan penelitian yang telah dilkakukan, maka dapat disimpulkan bahwa ada perbedaan kepuasan kerja pada driver ojek konvensional dan driver ojek online. Kepuasan kerja pada driver ojek online lebih tinggi dibandingkan kepuasan kerja pada driver ojek konvensional.

Adapun saran yang diajukan peneliti dari hasil penelitian ini adalah sebagai berikut:

1. Bagi subjek penelitian Bagi driver ojek konvensional dan driver ojek online, agar dapat memiliki keikhlasan, kesabaran dan kemampuan untuk bersyukur, sehingga profesi sebagai driver ojek dapat dijalankan dengan penuh tanggungjawab dan dedikasi terhadap keselamatan dan kepuasan 
konsumen (pelanggan).

2. Bagi Pengelola aplikasi ojek online. Bagi para pengelola aplikasi ojek online agar dapat mengembangkan teknologi untuk dapat melindungi dan menjaga keselamatan para driver ojek online.

3. Bagi masyarakat

Bagi masyarakat pengguna ojek online agar dapat bekerjasama dan mematuhi prosedur berkendaraan dijalan raya, sehingga keselamatan driver ojek dan penumpang dapat diupayakan bersama.

4. Bagi penelitian selanjutnya diharapkan dapat mengembangkan peneltian ini dengan menggunakan teori yang lebih baru terhadap variabel penelitian ini.

\section{Referensi}

Al Qarni, A. 2007. Tafsir Al Muyassar 3, Juz 17-24. Jakarta: Qisthi Press.

Al-Qarni, A., 2007. Tafsir Muyassar/ 'Aidh al- Qarni. Terjemahan. Jakarta : Qisthi Press Al Qarni, A. 2007. Tafsir Al Muyassar 1, Juz 1-8. Jakarta: Qisthi Press Al Qarni, A. 2007. Tafsir Al Muyassar 2, Juz 9-16. Jakarta: Qisthi Press.

Alhamdu. 2016. Analisis Statistik dengan Program SPSS. Palembang: Noer Fikri.

Almigo, N., 2004. Hubungan antara Kepuasan Kerja dengan Produktivitas Kerja Karyawan. Jurnal Psyche, vol 1, No 1, Desember 2004. hal 53-54.

Ana Ramadhayanti., 2016. Pengaruh Kualitas Layanan dan Kepuasan Konsumen terhadap Kinerja Ojek online. Widya Cipta, vol 8 No. 2.

Arikunto, 2013. Prosedur Penelitian Suatu Pendekatan Praktik. Jakarta: Rineka Cipta.

Azwar, S. 2010. Tes Prestasi. Yogyakarta: Pustaka Pelajar.
Azwar, S. 2015. Metode Penelitian. Yogyakarta: Pustaka Pelajar. Badudu, J.S dan Mohammad, S. 1994, Kamus Umum Bahasa Indonesia, Jakarta: PT. Integraphic.

Elshinta.com. Tertarik jadi Driver Transportasi Oniline, Pilih Grab, Gojek, atau Uber? Elshinta.com. Di akses_pada tanggal 7 November, 2017, dari, https: // elshinta.com /news/ 110867/2017 /06/ 12/tertarikjadi-driver- transportasi-online-pilihgrab-gojek- atau-uber

Erawati, dkk., 2008. Kepuasan Kerja pada Guru ditinjau dari Jenis Kelamin Kepala Sekolah. Jurnal Psikologi, vol, 1, 4, Juni 2008.

Irham, M. 2012. Etos Kerja dalam Perspektif Islam. Jurnal Substantia. Vol. 14, No. 1 April.

Kreither, R., dan Kinicki, A., 2003. perilaku Organisasi. Jakarta: Salemba Empat. Muhammad, A. 2003. Tafsir Ibnu Katsir. Jilid 4. Bogor: Pustaka Imam Syafei

Kumparan.com 250.000 Driver Gojek Kini Kuasai Jalanan Indonesia. m Kumparan.com. Di akses pada tanggal 7 November 2017, dari, https://www.google.co.id/amp/s/m.k umparan.com/ wisnu-prasetyo/250000-driver-go-jek-kini-kuasaijalanan-indonesia.amp.

Munandar, A. S., 2014. Psikologi_Industri dan Organisasi. Jakarta : UI Press.

Ojek Online. Pengetian dan Defenisi Ojek Online. Ojek Online. Diakses pada tanggal 7 November 2017 dari http://www.ojekonline.xyz/pengertia n-dan-definisi-ojek-online/Panji, A., 2006.

Psikologi Kerja. Jakarta: Rhenika Cipta Ramlan Ruvendi., 2005. Imbalan Dan Gaya Kepemimpinan Pengaruhnya Terhadap Kepuasan Kerja Karyawan Di Balai Besar Industri Hasil Pertanian Bogor. Jurnal Ilmiah Binaniaga Vol 01 No 1

Reza, I.R., 2017. Metode Penelitian psikologi Kuantitatif, Kualitatif, dan 
Kombinasi. Palembang: Noer Fikri.

Salim, P., dan Salim, Y., 1991, Kamus

Bahasa Indonesia, Edisi Jakarta: Intergraphic Yusuf, Y., 2013. Tafsir Khuluqun Azhim; Budi Pekerti Agung. Tangerang: Lentera Hati.

Shafira dan Anita Listira., 2017. Perbedaan

Kepuasan Kerja pada Karyawan berdasarkan Usia dan Masa Kerja. Jurnal Empati. Vol. 6(1).

Sugiono. 2015. Metode Penelitian Kuantitatif, Kualitatif, dan R\&D. Bandung: Alfabeta.

Sutarto Wijono., 2014. Psikologi Industri dan Organisasi. Jakarta : Kencana Media Group.

Sutrisno, S., 2009. Manajemen Sumber Daya Manusia. Jakarta: Kencana Prenada Media Group.

Suwatno dan Priansa, D.J., 2011. Manajemen SDM dalam Organisasi Publik dan Bisnis. Bandung:
Alfabeta.

Wibowo, 2007. Manajemen Kinerja. Jakarta : PT. Raja Grafindo Persada. Wijono, S. 2014. Psikologi Industri dan Organisasi; Dalam Suatu Bidang Gerak Psikologi Sumber Daya Manusia. Jakarta: Kencana.

Wita Farla WK., 2016. Analisis Kepuasan Kerja Karyawan Fakultas Ekonomi Univesitas Sriwijaya berdasarkan karakteristik Individu. Jurnal Manajemen dan Bisnis Sriwijaya, vol. 14, No. 3. vol. 14, No3.

Zainal, V.r., Ramly, M., Mutis, T., \& Arafah, W., 2014. Manajemen Sumber Daya Manusia untuk Perusahaan; dari teori ke praktik. Jakarta: Rajawali Press. (https://winamartiana.wordpress.com /2011/09/28/kepuasan-kerja/ di akses pada hari selasa, 5 Desember 2017, pukul 17.45 WIB. 